\title{
Correction to: Temperature Dependence of Thermoelectric Homogeneity of Noble Metal Thermocouples
}

\author{
${\text { Frank } \text { Edler }^{1} \text { D } \cdot \text { Kai Huang }}^{1}$
}

Published online: 5 May 2021

(C) The Author(s) 2021

\section{Correction to: International Journal of Thermophysics (2020) 41:22 https://doi.org/10.1007/s10765-019-2598-x}

The article "Temperature Dependence of Thermoelectric Homogeneity of Noble Metal Thermocouples", written by Frank Edler and Kai Huang, was originally published Online First without Open Access. After publication in volume 41, issue 2, page 1-13 the author decided to opt for Open Choice and to make the article Open Access publication. Therefore, the copyright of the article has been changed to (C) The Author(s) 2021 and the article is forthwith distributed under a Creative Commons Attribution 4.0 International License, which permits use, sharing, adaptation, distribution and reproduction in any medium or format, as long as you give appropriate credit to the original author(s) and the source, provide a link to the Creative Commons licence, and indicate if changes were made. The images or other third party material in this article are included in the article's Creative Commons licence, unless indicated otherwise in a credit line to the material. If material is not included in the article's Creative Commons licence and your intended use is not permitted by statutory regulation or exceeds the permitted use, you will need to obtain permission directly from the copyright holder. To view a copy of this licence, visit http://creat ivecommons.org/licenses/by/4.0.

Open Access This article is licensed under a Creative Commons Attribution 4.0 International License, which permits use, sharing, adaptation, distribution and reproduction in any medium or format, as long as you give appropriate credit to the original author(s) and the source, provide a link to the Creative Commons licence, and indicate if changes were made. The images or other third party material in this article are included in the article's Creative Commons licence, unless indicated otherwise in a credit line to the material. If material is not included in the article's Creative Commons licence and your intended use is not permitted by statutory regulation or exceeds the permitted use, you will need to obtain permission

The original article can be found online at https://doi.org/10.1007/s10765-019-2598-x.

Frank Edler

frank.edler@ptb.de

$1 \quad$ Physikalisch-Technische Bundesanstalt, Berlin, Germany 
directly from the copyright holder. To view a copy of this licence, visit http://creativecommons.org/licen ses/by/4.0/.

Publisher's Note Springer Nature remains neutral with regard to jurisdictional claims in published maps and institutional affiliations. 